Original Articles \title{
Feelings and expectations of mothers of preterm babies at
discharge*
}

\author{
Sentimentos e expectativas das mães na alta hospitalar do recém-nascido prematuro
}

Sentimientos y expectativas de las madres en el alta hospitalaria del recién nacido prematuro

\begin{abstract}
Maria Zuleide da Silva Rabelo ${ }^{1}$ Edna Maria Camelo Chaves², Maria Vera Lúcia Moreira Leitão Cardoso 3 , Maria do Socorro Mendonça Sherlock ${ }^{4}$
\end{abstract}

\begin{abstract}
Objective: To investigate the feelings and expectations of mothers of preterm babies at discharge. Methods: This descriptive study used Bardin's framework to collect data among 11 mothers of preterm babies from a Neonatal Intensive Care Unit. Data were collected through interviews from December 2004 to January 2005. Results: Four categories emerged: the moment of the discharge; mothers' knowledge and questions; mothers' preparation and orientation for discharge; and, mothers' desired orientation. Conclusion: Although mothers' experienced excitement and happiness at discharge, many reported being anxious and insecure on how to take care of their preterm babies.
\end{abstract}

Keywords: Infant, premature; Patient discharge; Intensive care units, neonatal; Anxiety; Mother-child relationships

\section{RESUMO}

Objetivo: Investigar os sentimentos e expectativas das mães de recém-nascidos prematuros no momento da alta hospitalar. Métodos: Estudo com abordagem qualitativa, desenvolvido com mães de recém-nascidos prematuros internados numa Unidade de Terapia Intensiva Neonatal. Os dados foram coletados por meio de entrevista, no período de dezembro/2004 a janeiro/2005. Os sujeitos foram 11 mães que vivenciavam a alta hospitalar do filho. A organização dos dados foi baseada em Bardin. Resultados: Da análise emergiram quatro categorias: Momento da alta hospitalar, Dúvidas maternas, Preparo e orientações para alta, Orientações almejadas pelas mães. Conclusão: Os sentimentos expressos pelas mães foram alegria, ansiedade e insegurança na alta hospitalar do filho.

Descritores: Prematuro; Alta do paciente; Unidades de terapia intensiva neonatal; Ansiedade; Relações mãe-filho

\section{RESUMEN}

Objetivo: Investigar los sentimientos y expectativas de madres de recién nacidos prematuros en el momento del alta hospitalaria. Métodos: Se trata de un estudio con abordaje cualitativo, desarrollado con madres de recién nacidos prematuros internados en una Unidad de Cuidados Intensivos Neonatal. Los datos fueron recolectados por medio de entrevista, en el período de diciembre/2004 a enero/2005. Los sujetos fueron 11 madres que vivenciaban el alta hospitalaria del hijo. La organización de los datos estuvo fundamentada en Bardin. Resultados: Del análisis emergieron cuatro categorías: Momento del alta hospitalaria, Dudas maternas, Preparación y orientaciones para el alta, Orientaciones deseadas por las madres. Conclusión: Los sentimientos expresados por las madres fueron alegría, ansiedad e inseguridad en el alta hospitalaria del hijo.

Descriptores: Prematuro; Alta del paciente; Unidades de Cuidados intensivos neonatal; Ansiedad; Relaciones madre-hijo

\footnotetext{
* Study carried out in a Public Maternity Hospital in Fortaleza (CE).

${ }^{1}$ Nurse at the Neonatal Unit at Hospital Dr César Cals - Fortaleza (CE), Brazil.

${ }^{2}$ Nurse at the Neonatal Unit at the Fortaleza General Hospital. Master in Child and Adolescent Health-Ceara Federal University-UFC-Fortaleza (CE). Brazil. Masters student at the Clinical Care Course UECE.

${ }^{3}$ Post-doctorate/Canada. Associate Professor at the Ceara Federal University (UFC) - Nursing Department; Fortaleza (CE), Brazil.

${ }^{4}$ MNS, Coordinator of the Neonatal Specialization Course - Ceara Federal University-UFC-Fortaleza (CE), Brazil.
} 


\section{INTRODUCTION}

Pregnant women and their families usually have hopes and expectations regarding the birth of the new baby. They wish for a healthy, stable birth, filled with joy. However, in some cases, births occur earlier than expected. When this happens, and the baby is born premature, the anticipated idealizations change to anguish and uncertainties in the lives of the couple and family, since the baby is at risk due to anatomical and physiological immaturity. Premature birth is an aggression to the fetus, since it is in the last intrauterine stage and its organs are being developed, thus still morphologically and functionally immature ${ }^{(1)}$. Preterm newborns are those born with less than 37 complete gestational weeks, and are classified according to the gestational age: borderline, moderately, and extremely premature; and according to birth weight: very low birth weight and extremely low birth weight ${ }^{(2)}$.

The baby's extensive period of hospitalization in the Neonatal Intensive Care Unit (NICU) impairs the establishment of maternal bonding and attachment. This separation favors mothers' feelings of insecurity toward taking care of her child. In the postpartum period, mothers are usually insecure and feel guilty for not having had the organic capacity of generating a healthy child. Most preterm infants are born ill and the mother, in this context, experiences several feelings, like fear, uncertainty, and anguish ${ }^{(3)}$.

Nurses, in this context, have an important role in the moments of interaction and care of the mother-child binomial. Our experience in the NICU permitted to follow, through the years, the moments experienced by the babies' parents within the unit, who often question themselves about the possibility of taking their child home. As families are inserted in the everyday routine of the NICU, they experience the feelings of having a premature child, who will require long-term special care, including after hospital discharge ${ }^{(4)}$.

Hospital discharge is a moment of great expectation to the family. This is especially true for those who will be receiving a premature baby to their environment, since this baby, with his/her particularities, will demand more intensive care. To the mother, this generates obscurities regarding her competency of taking care of that baby. In this moment, the health staff should be prepared with patience, organization, knowledge, and competency to assist mothers in this transition process, and provide instructions in terms of her responsibility and dedication in view of the baby's health condition.

An effectively planned hospital discharge would guarantee the continuity of hospital care within the household ${ }^{(5)}$. This planning should take into consideration the specific needs of the family and newborn, and establish clear, simple goals.
In view of this issue, we felt the urge to learn about the mothers' expectations toward their child's discharge from the NICU, where the babies receive care exclusively from the specialized health staff, and not from their mothers, with whom they were attached for months "in the womb". Hence, the purpose of this study is to investigate mothers' feelings and expectations regarding their premature child's hospital discharge.

\section{METHODS}

This is a qualitative study, developed with mothers of preterm newborns hospitalized at NICUs. The study setting was a NICU in a public maternity-hospital in the city of Fortaleza, Ceara State, Brazil. This institution is a reference for high-risk pregnant women. The NICU consists of 24 intensive therapy beds and 30 mediumrisk beds. It is equipped with oximeters, monitors, incubators, respirators, and infusion bombs. The health staff consisted of physicians, nurses, nurse auxiliaries, speech therapists, social workers, occupational therapists, and several service workers.

The studied subjects were 11 mothers of preterm newborns hospitalized in NICU at the moment the data were collected, from December/2004 to January/2005. The instrument used was a form with questions about the mothers' feelings and expectations regarding their premature child's discharge from the NICU. One of the researchers registered the data, by hand, after receiving written informed consent from the mothers.

The data were organized in the first research stage, and a comprehensive, superficial reading of the content was carried out. Next, the material was explored through exhaustive readings. The content was, therefore, coded and categorized according to the statements' convergence ${ }^{(())}$, and analyzed according to references pertinent to the theme. The following categories emerged: the moment of hospital discharge, maternal doubts, preparation and instructions for discharge, instructions sought after by the mothers.

Regarding ethical aspects, this study was approved by the Institutional Review Board, in agreement with Resolution n. ${ }^{\circ}$ 196/96 of the National Health Council/ Health Ministry, concerning research with human beings ${ }^{(7)}$. Mothers were invited to participate through written postinformed consent, and were assured that secrecy and anonymity would be preserved. To protect their true identity, subjects were identified using flower names. The study took into consideration the primary Bioethics presuppositions, arranged in the aforementioned resolution - autonomy, nonmaleficence, beneficence, and justice.

\section{RESULTS}

The analysis of the mothers' statements yielded the 
following categories: the moment of hospital discharge; maternal doubts; preparation and instructions for discharge; and instructions sought after by the mothers. Each category will be presented below.

Category: The moment of hospital discharge

\section{[...]feel like crying. (Poppy)}

Very happy with my son by my side. (Camellia)

What a relief, I have three other children to raise, I'm from the inner state. (Begonia)

Happy, because I live far away, it was hard to come to visit. Now everyone is waiting for the baby to arrive (Daisy).

I'm feeling anxious and happy, but also a little afraid (Jasmine).

This category shows the main feelings expressed through mothers' statements, focused on crying, happiness, relief, and fear many times related to their other children and relatives who stayed home.

Category: Maternal doubts

I'm afraid of the baby having to return, I think they could talk more about the premature baby, about the risks [...]. (Violet)

My doubt is about bathing, holding him, because he is so small. (Jasmine)

I had some already, but by being here I learned, because I'm with the baby all the time. (Begonia)

Since I stayed here a long time, one month, I've learned how bathe, change diapers, and breastfeed. (Daisy)

From the mothers' reports, it is observed that activities like bathing, forms of holding, changing diapers, and breastfeeding, become complex when taking care of a premature baby.

Category: Preparation and instructions for discharge

I received instructions about health care and bygiene, and cautions with visits. (Rose)

Just normal instructions about follow-up visits and vitamins. (Gerbera)

I'm leaving, and until now I didn't receive any instructions. (Orchid)

I didn't receive any instructions, I mean only at the bealth unit, bow to feed and bathe. (Violet)

I received instructions about hoe to breastfeed, bathe, change diapers, and take care. (Lilly)

Preparation for discharge refers to instructions about care with hygiene, feeding - focused on breastfeeding, administrating medications, and returning to the outpatient clinic for followup visits. The mothers reinforce their need to receive instructions at the moment of their child's hospital discharge.

Category: Instructions sought after by the mothers

I think lectures about taking care of a premature baby, a manual, I don't know, something to belp us in the everyday life. (White Lilly)

They should talk with us. (Gerbera)

A handbook with instructions about elimination, like if it's normal for the baby to go two days without defecating. And if having nose congestion is something common for every premature baby (Poppy)

They could make a manual about what the baby might have. The other day I got really scared, the baby regurgitated, and milk came out of her nose, I went crayy. What if this happened at home? What would I do? (Orchid)

I'm afraid of the baby having to return, I think they could talk more about the premature baby, about the risks [...]. (Violet)

In view of the statements, it is observed there is a need for educational material covering the care that should be offered to newborns in risk situations.

\section{DISCUSSION}

Premature newborn health care, over time, has been given through a more humanistic and holistic approach, focused on the health-disease process. Mothers should be prepared throughout the entire hospitalization period, as an attempt to reduce their expectations that could impair the family's adjustment to the premature baby.

Despite their motherhood experience, the participant mothers were living the same situation, that is, a momentarily separation from their child due to the premature birth. It is observed that the health staff should pay closer attention to this situation. It is important to recognize that parents need just as much attention from the NICU physicians and nurses as do their newborns ${ }^{(8)}$.

Taking into consideration the category "the moment of hospital discharge", prematurity is clearly the main cause for NICU hospitalization, and the major concern of the multidisciplinary team is not simply survival, but, mainly, quality of life. When the so expected moment of hospital discharge arrives, parents burst with feelings of tranquility, joy, and anxiety. A child's birth is one of the most challenging events for the parents, because it is an opportunity of personal growth and maturity, as well as the chance of becoming a family ${ }^{(8)}$.

Parents should be prepared for temporary changes to their lives, imposed by the arrival of a premature newborn. Ambivalence and fear are two common feelings, while preparations for hospital discharge are underway ${ }^{(9)}$. Going home is a new obstacle. Regardless of their acquired experience, parents will be facing a rather problematic period, considering the worry and fear of their child no longer being in the hands of the NICU staff. From now on, they will be the ones responsible for their baby's safety ${ }^{(10)}$. The fear of becoming fully responsible for the baby induces feelings on the mother and family that require 
careful attention. It is a process that involves affective attachment and skills, since the act of touching and caring can, initially, originate anxieties, for the health staff is no longer present to solve doubts and difficulties. When the time comes for mothers to take the responsibility for looking after their child, they reveal the fear of the first experiences, like holding and breastfeeding ${ }^{(3)}$. The health team is supposed to, at the moment of discharge, be comprehensive and empathetic so as to provide the necessary information. When appropriately taught how to care for and understand their child, in a way that their needs are completely fulfilled, mothers become a health multiplying agent within individual, family, social, and ecological environments ${ }^{(11)}$.

The second category "Maternal doubts" evokes the discussion that the time that mothers stay in the NICU contributes to reestablish the affective attachment with their child, in addition to being a moment in which they can participate in the care, and thus develop their skills. Approximation favors the relationship conditions and establishes credibility, trust, and support in difficult moments ${ }^{(12)}$. Welcoming mothers that come to the NICU to visit their hospitalized child is a form of diminishing feelings of separation, which raises doubts and questions $^{(13)}$.

The presence of relatives in the daily routine at the NICU has become increasingly common as a result of the proposal for health care humanization to these clients. Humane care involves presence and dialogue with those who require health care, respecting his/her singularity and individuality ${ }^{(14)}$. Therefore, mothers report that their presence during moments when their babies were being taken care of, either during bathing, diaper change, or feeding, meant learning opportunities for them. Mothers' participation in taking care of the baby is advantageous and should take place under direct nursing supervision. It is important to fulfill all adult learning needs, stressing their participation and the active participation of the learners $^{(11)}$.

It should be emphasized that the attention toward mothers visiting their premature children at the NICU should be continuous, so they could become true health promotion collaborators. They should be able to understand the treatment used, and acquire certain skills considered essential to care for the baby at home. Thus, depending on the baby's clinical condition, being welcomed into the household will require much readiness and understanding from the family.

The mothers reported the advantage of being in the NICU, often just observing the procedures, but learning details about the health care strategies. Nevertheless, the health staff should invest more time welcoming mothers to the NICU, since they largely focus on the technological support or give superficial or synthetic information, mainly regarding the baby's diagnoses and prognoses.

Regarding the category "preparation and instruction for discharge", it is stressed that instructions offered to prepare parents for the baby's discharge should be clear, concise, and simple; easy to understand. The nursing staff should be sensitive to factors like stress and anxiety, which could affect learning, because the ideal moment for learning is when mothers show the motivation and availability to learn ${ }^{(15)}$.

NICU nurses should encourage and favor situations that permit parents to participate in their child's health care to strengthen the attachment between the motherchild binomial, as well as to increase the mother's level of security as a caregiver. This is especially true since a successful discharge outcome depends on the work of the multidisciplinary team while the newborn is hospitalized.

It is the nurses' responsibilities to oversee mothers develop skills, despite the difficulties since they are understaffed in the NICU. Nurses perform several administrative and supervision tasks, leaving little time to directly care for babies and their families, due to the overload of hospitalized babies ${ }^{(16)}$.

The attention to mothers should be implemented in procedures like changing diapers, soothing when the baby cries, when encouraging mothers to touch and caress their child, when assisting mothers while milking to feed the baby in case breastfeeding is not possible. If moments like these are experienced with eagerness, understanding, and dialogue, mothers can become true health multiplying agents for relatives, besides contributing to enhancing the feeling of security in situations of emotional fragility.

The mother's voice and actions toward her child should be closely observed during nursing care, because these details could indicate the mother's readiness to care for her child ${ }^{(17)}$. The newborn's movements are indicators of this interaction. In most hospitals, nurses and social workers are directly responsible for the discharge preparation, while physicians provide instructions about special medical needs ${ }^{(9)}$.

Although the reviewed literature explains the magnitude of what it means to provide mothers, or other responsible adults, with knowledge and instructions, some study participants reported not receiving information about how to take care of their child after hospital discharge; others reported having received information about hygiene, feeding, and using vitamins. These instructions are, in fact, relevant. However, the health staff should be careful in terms of the language used, and avoid common technical jargons in these situations. Communication should be clear and respect the mothers' level of understanding, besides giving them the opportunity to make questions and ask for repetition, in cases the message was not well understood ${ }^{(18)}$. 
Appropriate communication reduces anxiety and enhances the clients' ability to understand the information they receive.

In the category "Instructions sought after by the mothers", it was stressed that determining what parents need to know to take care of their baby is one of the most complex aspects involved in hospital discharge. No matter how simple the newborn's situation, parents are also anxious about getting attention from the health staff. They are thirsty for effective communication, regardless of the environment.

Parents with a premature baby need preparation to safely take care of their child at home. Hospitals in general, but especially those with patients from a wide range of socioeconomic and cultural backgrounds, should consider these differences in their educational approaches ${ }^{(9)}$. Appropriate language and instruction should be considered in the education plans. Instructing families about how to take care of their premature or ill newborns requires a well structured and documented approach.

If the moment of discharge is provided with organization and planning, nurses can use several means of information, through verbal and non-verbal communication, like the demonstration of certain procedures that will be performed by the relatives at home. In addition, the hospital could create informational fliers and manuals using pictorial communication and simple language, with pictures of mothers performing hygiene, visual and motor stimulation, feeding techniques, and others. The educational materials used in Health Education activities encourage the mothers' participation in the learning process ${ }^{(4)}$. NICU health care professionals should encourage the parents' participation, which would help them to overcome the difficulties experienced with the birth of a premature child.

\section{CONCLUSIONS}

The long NICU hospitalization period impairs the establishment of maternal bonding and attachment. This separation favors mothers' feelings of insecurity regarding taking care of her child. It was observed that parents experienced moments of uncertainty in the NICU, in which they often ask about the possibility of taking their baby home.

The NICU environment, in addition to the baby's prematurity condition, resulted in fear, doubts, and the mothers' lack of confidence toward their child. However, the period that mothers stayed in the NICU contributes with reestablishing the affective bonding and is also a moment when mothers can participate in health care, developing their skills and reducing doubts that could appear at hospital discharge. In this view, it is the health staff's responsibility to involve parents in the newborns' hygiene and health care procedures, so as to increase their security during hospitalization, thus assuring that after discharge they will feel safe to take care of their child at home. There is clear conviction that the NICU health team, who endeavors for newborns to go home, should adopt the mothers as participative members during the hospitalization period, which will be decisive for a successful hospital discharge.

\section{REFERENCES}

1. Alves Filho N, Correa MD, colab. Manual de perinatologia. 2a. ed. Rio de Janeiro: MEDSI; 1995.

2. Marcondes E, coord. Pediatria básica. 8a ed. São Paulo: Sarvier; 1992.

3. Reichert APS, Costa SFG. Refletindo a assistência de enfermagem ao binômio mãe e recém-nascido prematuro na unidade neonatal. Nursing (São Paulo). 2001;4(38):25-9.

4. Fonseca LMM, Scochi CGS, Rocha SMM, Leite AM. Cartilha educativa para orientação materna sobre os cuidados com o bebê prematuro. Rev Latinoam Enfermagem. 2004;12(1):65-75.

5. Clohert JP, Stark AR. Manual de neonatologia. 4a. ed. Rio de Janeiro: Medsi; 2000. p. 171-81.

6. Bardin L. Análise de conteúdo. 3a ed. Lisboa: Edições 70; 2004.

7. Brasil. Ministério da Saúde. Diretrizes e normas regulamentadoras de pesquisa envolvendo seres humanos: resolução 196/96. Brasília: Conselho Nacional de Saúde; 1996. 12p.

8. Brazelton TB. Desenvolvimento do apego. Porto Alegre: Artes Médicas; 1988. 208 p.

9. Avery GB, Fletcher MA, MacDonald MG. Neonatologia: fisiopatologia e tratamento do recém-nascido. 4 a ed. Rio de Janeiro: MEDSI; 1999.

10. Gaíva MAM, Ferriani MGC. Prematuridade: vivências de crianças e familiares. Acta Paul Enfermagem. 2001;14(1):17-27.

11. Fonseca LMM, Scochi CGS, Mello DF. Educação em saúde de puérperas em alojamento conjunto neonatal: aquisição de conhecimento mediado pelo uso de um jogo educativo. Rev Latinoam Enfermagem. 2002;10(2):166-71.

12. Alencar AJC, Rolim KMC. O cuidado ao binômio mãe e filho: um enfoque humanístico. Rev Pediatr Ceará. 2003;4(2):48-51.

13. Campos ACS. O significado de ser mãe de um recém-nascido sob fototerapia: uma abordagem humanística. [dissertação]. Fortaleza: Universidade Federal do Ceará. Programa de PósGraduação em Enfermagem; 2003. 154p.

14. Paterson JG, Zderad LT. Humanistic nursing. New York: National League for Nursing; 1988. 129p.

15. Tamez RN, Silva MJP. Enfermagem na UTI neonatal: assistência ao recém-nascido de alto risco. $2 \mathrm{a}$ ed. Rio de Janeiro: Gunanabara Koogan; 2002.

16. Rolim KMC. A enfermagem e o recém-nascido de risco: refletindo sobre a atenção humanizada [tese]. Fortaleza: Universidade Federal do Ceará. Programa de Pós-Graduação em Enfermagem; 2003.

17. Rocha SMM, Simpionato E, Mello DF. Apego mãe-filho: estudo comparativo entre mães de parto normal e cesárea. Rev Bras Enfermagem. 2003;56(2):125-9.

18. Lopes CLR, Barbosa MA, Teixeira MEM, Coelho RB. A comunicação profissional de saúde X cliente diante das novas tecnologias. Rev Bras Enfermagem. 1998;51(1): 53-62. 